\title{
Rapid Biodegradation of the Organophosphorus Insecticide Chlorpyrifos by Cupriavidus nantongensis $\mathrm{X1}^{\mathrm{T}}$
}

\author{
Taozhong Shi ${ }^{\dagger}$, Liancheng Fang ${ }^{+} \mathbb{C}$, Han Qin, Yifei Chen, Xiangwei Wu and Rimao Hua * \\ Key Laboratory for Agri-Food Safety, School of Resource \& Environment, Anhui Agricultural University, \\ Hefei 230036, Anhui, China; tzs@ahau.edu.cn (T.S.); fang8232335@ahau.edu.cn (L.F.); \\ HanQin@ahau.edu.cn (H.Q.); ahaucyf2016@ahau.edu.cn (Y.C.); wxwahau@ahau.edu.cn (X.W.) \\ * Correspondence: rimaohua@ahau.edu.cn; Tel.: +86-551-65786320; Fax: +86-551-65786296 \\ + Taozhong Shi and Liancheng Fang contributed equally to this paper.
}

Received: 11 October 2019; Accepted: 19 November 2019; Published: 20 November 2019

\begin{abstract}
Chlorpyrifos was one of the most widely used organophosphorus insecticides and the neurotoxicity and genotoxicity of chlorpyrifos to mammals, aquatic organisms and other non-target organisms have caused much public concern. Cupriavidus nantongensis $\mathrm{X} 1^{\mathrm{T}}$, a type of strain of the genus Cupriavidus, is capable of efficiently degrading $200 \mathrm{mg} / \mathrm{L}$ of chlorpyrifos within $48 \mathrm{~h}$. This is $\sim 100$ fold faster than Enterobacter B-14, a well-studied chlorpyrifos-degrading bacterial strain. Strain $\mathrm{X} 1^{\mathrm{T}}$ can tolerate high concentrations $(500 \mathrm{mg} / \mathrm{L})$ of chlorpyrifos over a wide range of temperatures $\left(30-42{ }^{\circ} \mathrm{C}\right)$ and $\mathrm{pH}$ values (5-9). RT-qPCR analysis showed that the organophosphorus hydrolase $(\mathrm{OpdB})$ in strain $\mathrm{X} 1^{\mathrm{T}}$ was an inducible enzyme, and the crude enzyme isolated in vitro could still maintain $75 \%$ degradation activity. Strain $X 1^{\mathrm{T}}$ can simultaneously degrade chlorpyrifos and its main hydrolysate 3,5,6-trichloro-2-pyridinol. TCP could be further metabolized through stepwise oxidative dechlorination and further opening of the benzene ring to be completely degraded by the tricarboxylic acid cycle. The results provide a potential means for the remediation of chlorpyrifos- contaminated soil and water.
\end{abstract}

Keywords: biodegradation; chlorpyrifos; Cupriavidus nantongensis $\mathrm{X} 1^{\mathrm{T}}$; OpdB

\section{Introduction}

Chlorpyrifos (O,O-diethyl-O-(3,5,6-trichloro-2-pyridinol) phosphorothioate, is an organophosphorus insecticide, nematicide, and acaricide, which was first commercialized in the USA by Dow Chemical Co. (Midland, MI, USA) in 1965 [1]. Chlorpyrifos has been widely used to protect a wide variety of crops, including cereals, fruits, vines, vegetables, ornamentals, cotton and other economic crops to control rice leaf moth, plant hoppers, gall midge, wheat army worm, cotton boll worm, aphid and red spider [2]. Chlorpyrifos also had an effect against soil insects and livestock parasites. However this widespread and frequent application of chlorpyrifos has caused several toxicological, environmental contamination and residue problems, which seriously threaten human health, as well as ecological and environment security [3,4]. To date, residues have been detected in marine sediments, rivers, lakes, groundwater, urban sewage systems, and even in rain and air in the United States and Mexico [5]. Along the Mediterranean coast, especially in Turkey, chlorpyrifos residues were the most high-frequency insecticide detected in environment [6].

Various toxic effects caused by chlorpyrifos have been reported. Previous studies have shown that chlorpyrifos not only has acute and chronic toxicity to mammals, aquatic organisms and other non-target organisms, but also has neurotoxicity, genotoxicity and other multiple toxic influences $[7,8]$. 
Therefore, it is urgent to repair any environment contaminated by chlorpyrifos. Numerous significant studies related to the repair of soil and water pollution by chlorpyrifos were reported, including photochemical degradation using physical and chemical methods, nanometal materials or $\mathrm{UV} / \mathrm{H}_{2} \mathrm{O}_{2}$ catalytic degradation $[9,10]$. Compared with these methods, biodegradation is an efficient and environmental friendly method to repair soil and water contaminated by chlorpyrifos [11].

At present, a variety of microorganisms capable of degrading chlorpyrifos have been isolated and identified from the environment, like Pseudomonas sp. CB2 [12], Paracoccus sp. TRP [13], Sphingomonas sp. Dsp-2 [14], Alcaligenes faecalis DSP3, Streptomyces sp.AC5, Bacillus cereus MCAS02, Cupriavidus sp. DT-1 [15], Ochrobactrum sp. JAS2 [16], etc. 3,5,6-Trichloro-2-pyridinol (TCP) and diethylthiophosphoric acid (DETP) are the main metabolites of chlorpyrifos obtained by biodegradation [17]. TCP has been listed as a persistent and mobile organic pollutant by the U.S. Environmental Protection Agency (EPA) due to its higher solubility in water and longer half-life (65-360 days) than its parent compound chlorpyrifos [18]. It has reported that a combination of chlorpyrifos and TCP could cause greater toxic effects than either alone [19]. However, most bacteria can only degrade chlorpyrifos but not TCP. Only a few bacteria capable simultaneously degrade both chlorpyrifos and TCP [20]. Therefore, it is of great significance to select a strain that can efficient degrade chlorpyrifos and TCP simultaneously.

Chlorpyrifos commonly undergoes three metabolic pathways: (1) Alkylation pathway, where the main metabolite TCP can further generate 3,5,6-trichloro-2-methypyridine (TMP) or 3,5,6-trichloro-2-methoxypyridine (TCMP) by alkylation reactions [21]. (2) Reductive dechlorination pathway, in which TCP is first dechlorinated to chlorodihydro-2-pyridone, and then dechlorinated further to tetrahydro-2-pyridone, and then the pyridine ring is cleaved to form maleamide semialdehyde, and finally mineralized to $\mathrm{CO}_{2}$, ammonium ion, water, and other inorganic materials [1]. (3) Oxidative dechlorination pathway. Bhuimbar et al. reported that Micrococcus luteus and Bacillus subtilis can further dechlorinate the para and ortho- $\mathrm{Cl}$ atoms in TCP to form 3,6-dihydroxypyridyl-2,5-diketone through oxidation reactions [22]. However, some key intermediate metabolites were not detected due to their unstable structures and low concentration.

Microbial degradation of organic pollutants is generally considered to be caused by enzymes. Phosphoric triester hydrolases (EC 3.1.8), the most studied chlorpyrifos-degrading enzymes, include methyl parathion hydrolase (MPH), OP acid anhydrolase (OPAA), OP degradation enzyme (OPD), phosphotriesterase (PTE) and glycerophosphodiesterase (GPD) [23,24]. All these enzymes belong to the metalloenzymes class and have a bivalent cationic bimetallic activity center. Among these enzymes, the substrates of OPD are the most extensive and toxic [25].

Cupriavidus nantongensis $\mathrm{X} 1^{\mathrm{T}}$ was recently isolated from an active sludge found at an organophosphorus insecticide manufacturing site in Nantong (Jiangsu Province, China). It was identified to be a novel species (type strain) of the genus Cupriavidus and complete genome sequencing showed that strain $\mathrm{X} 1^{\mathrm{T}}$ have the degradation gene opdB (encoding organophosphate hydrolase) in an original plasmid pX1 [26,27]. In this study, the high efficiency ability to degrade chlorpyrifos by strain $X 1^{\mathrm{T}}$ was evaluated. Optimum degradation conditions $(\mathrm{pH}$, temperature and inoculation) were determined and the degradation kinetics were characterized. A complete metabolic pathway was found and the oxidative dechlorination pathway of chlorpyrifos was improved.

\section{Materials and Methods}

\subsection{Chemicals and Culture Medium}

Chlorpyrifos (purity $=98.5 \%$ ) was purchased from Dr. Ehrenstorfer GmbH (Augsburg, Germany). The metabolite 3,5,6-trichloro-2-pyridinol $(\mathrm{TCP}$, purity $=95 \%)$ was purchased from J\&K Scientific (Beijing, China). Chromatographic grade solvents, including methanol, acetonitrile and formic acid, were purchased from Merck (Darmstadt, Germany). All other reagents were analytical or HPLC grade.

The Luria-Bertani (LB) medium contained $10 \mathrm{~g} / \mathrm{L}$ tryptone, $5 \mathrm{~g} / \mathrm{L}$ yeast extract powder and $10 \mathrm{~g} / \mathrm{L}$ $\mathrm{NaCl}$ in deionized water at $\mathrm{pH} 7.0$. LB solid medium was prepared by adding $2 \%$ agar powder. Mineral 
salt medium (MSM) contained $1 \mathrm{~g} / \mathrm{L} \mathrm{NaCl}, 0.1 \mathrm{~g} / \mathrm{L} \mathrm{MgSO} 4 \cdot 7 \mathrm{H}_{2} \mathrm{O}, 0.3 \mathrm{~g} / \mathrm{L} \mathrm{KH}_{2} \mathrm{PO}_{4}$, and $1 \mathrm{~g} / \mathrm{L} \mathrm{K} 2 \mathrm{HPO}_{4}$ in deionized water at $\mathrm{pH} 7.0$.

\subsection{Inoculum Preparation}

A single colony of activated $\mathrm{X} 1^{\mathrm{T}}$ bacteria was transferred into $100 \mathrm{~mL}$ LB culture medium and incubated overnight (about $16 \mathrm{~h}$, at the exponential growth phase) at $37^{\circ} \mathrm{C}$ with $150 \mathrm{rpm}$ on a rotary shaker. The cells were harvested after centrifugation (6000 rpm, $10 \mathrm{~min})$ and washed twice with MSM. Then the cells were re-suspended in MSM and adjusted optical density (OD) value to $0.6\left(\sim 1 \times 10^{8}\right.$ colony forming unit, $\mathrm{CFU})$ at a wavelength of $600 \mathrm{~nm}\left(\mathrm{OD}_{600}\right)$ by UV-1800 type spectrophotometer (Shimadzu Corp., Kyoto, Japan).

\subsection{Degradation of Chlorpyrifos by Strain $X 1^{T}$}

Chlorpyrifos was added to MSM as the only carbon source. A standard reaction sample $(20 \mathrm{~mL})$ was contained $50 \mathrm{mg} / \mathrm{L}$ chlorpyrifos, $18 \mathrm{~mL}$ MSM and $2 \mathrm{~mL}$ suspensions of strain $\mathrm{X}^{\mathrm{T}}\left(\mathrm{OD}_{600}=0.6\right)$. All samples were incubated at $150 \mathrm{rpm}$ and $37^{\circ} \mathrm{C}$ with three replicates. The negative control was inoculated without cell suspensions of strain $\mathrm{X} 1^{\mathrm{T}}$ under the same conditions. $20 \mathrm{~mL}$ pure acetonitrile was added to terminate the reaction and extract the residual chlorpyrifos and metabolites. All tubes were periodically sampled to measure residual chlorpyrifos and metabolites by UPLC.

To achieve optimum conditions for chlorpyrifos degradation by strain $\mathrm{X} 1^{\mathrm{T}}$, the inoculation volumes, $\mathrm{pH}$ and temperature were explored separately. The effects of inoculation volumes on the biodegradation of chlorpyrifos was determined at level of $1 \%, 2 \%, 5 \%, 10 \%$ and $20 \%$ (the total volume of the reaction samples) under the condition of $37^{\circ} \mathrm{C}$ and $\mathrm{pH}$. The effects of temperature on chlorpyrifos were evaluated at $20,30,37,42$ and $47^{\circ} \mathrm{C}$ under the condition of $10 \%$ inoculation volumes and $\mathrm{pH} 7$. The effects of $\mathrm{pH}$ were adjusted at 5, 6, 7, 8 and 9 under the condition of $10 \%$ inoculation volumes and $37^{\circ} \mathrm{C}$.

\subsection{Determination of Chlorpyrifos and TCP}

Acetonitrile $(20 \mathrm{~mL})$ was added to each sample which was then centrifuged at $6000 \times g$ for $5 \mathrm{~min}$. The supernatant was filtered through a 0.22- $\mu \mathrm{m}$ PTFE membrane prior to detection of the residues on an Acquity UPLC system (Waters Corp., Milford, MA, USA) coupled with a PDA detector (Waters Corp.) at $300 \mathrm{~nm}$ wavelength [20]. Chlorpyrifos and TCP were simultaneously isolated and detected by a BEH $C_{18}$ column $(1.7 \mu \mathrm{m}, 2.1 \mathrm{~mm} \times 50 \mathrm{~mm}$ ) (Waters Corp., Wexford, Ireland). The column temperature was $40{ }^{\circ} \mathrm{C}$. The mobile phase was composed of solvent $\mathrm{A}(0.1 \%$ formic acid in water), and solvent $\mathrm{B}(0.1 \%$ formic acid in acetonitrile) at a constant flow rate of $0.5 \mathrm{~mL} / \mathrm{min}$. The gradient elution was programmed to increase the amount of solvent $B$ from an initial $5 \%$ (maintained for $0.25 \mathrm{~min}$ ) to $95 \%$ in $2.75 \mathrm{~min}$, stabilize at $95 \%$ for $0.5 \mathrm{~min}$, and then return to the initial conditions ( $5 \% \mathrm{~B}$ ) in $0.01 \mathrm{~min}$. The retention time of TCP and chlorpyrifos were 1.937 and $2.919 \mathrm{~min}$, respectively.

\subsection{RT-qPCR Analysis of the Expression of Chlorpyrifos Degradation Gene}

Through previous complete genome sequencing of strain $X 1^{\mathrm{T}}$, the gene responsible for degradation of chlorpyrifos was identified to be the opdB gene, encoding organophosphorus hydrolase. The relative expression of degradation gene (opdB) was determined by the RT-qPCR method. Strain $X 1^{\mathrm{T}}(10 \%$ inoculation) was added to the MSM containing $50 \mathrm{mg} / \mathrm{L}$ chlorpyrifos and incubated at $150 \mathrm{rpm}$ and $37^{\circ} \mathrm{C}$. The negative control was inoculated without cell suspensions of strain $\mathrm{X} 1^{\mathrm{T}}$ under the same condition. All tubes were periodically sampled at $0 \mathrm{~h}, 2 \mathrm{~h}, 4 \mathrm{~h}, 8 \mathrm{~h}$ and $12 \mathrm{~h}$. The cells were collected and total RNA was extracted by an EasyPure RNA kit (TransGen Biotech, Beijing, China). Then, total RNA was purified by an AccuRT Genomic DNA removal kit (Applied Biological Materials Inc. Vancouver, Canada) and transcripted to cDNA by a TranScript cDNA synthesis supermix kit (TransGen Biotech, Beijing, China). The housekeeping gene (rpoB) was commonly used and selected to compare the 
expression of chlorpyrifos degradation gene (opdB), previously reported [20]. The primers used were as follows: rpoB-F CTGCTTGCCACCCAGATTGA, rpoB-R AGCCCGTTATGCGAGGAGAT. opdB-F CTAAACGGGCAACGACAGATT and opdB-R CAATGGCGAATTGGGTGTGTA. The RT-qPCR procedure were as follows: polymerase was activated at $95^{\circ} \mathrm{C}$ for $3 \mathrm{~min}$, followed by 40 cycles at $95^{\circ} \mathrm{C}$ for $10 \mathrm{~s}$ and $58^{\circ} \mathrm{C}$ for $30 \mathrm{~s}$.

The CT values of reference genes (rpoB) and target gene (opdB) in all samples were determined respectively. The relative expression of the target gene (opdB) to the reference gene (rpoB) was calculated by the following formula:

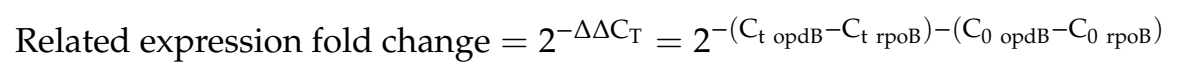

$C_{t \text { opdB }}$ and $C_{t \text { rpoB }}$ are $C_{T}$ values of target gene and reference gene at different time, respectively. $C_{0 \text { opdB }}$ and $C_{0 \text { rров }}$ are $C_{T}$ values of target gene and reference gene at initial time, respectively. The related expression of opdB with house-keeping gene rpoB was collected and calculated using the BioRad CFX manager 3.1 software (Hercules, CA, USA).

\subsection{Determination of the Metabolites of Chlorpyrifos by Strain $X 1^{T}$}

The metabolites were analyzed on an Acquity UPLC system coupled with a triple quadrupole mass spectrometer (Xevo TQ-MS, Waters Corp. Ltd.) and fitted with an ESI interface and controlled by the MassLynx 4.1 software (Waters, Milford, MA, USA). Metabolites in samples were separated by a BEH C $_{18}$ chromatographic column $(1.7 \mu \mathrm{m}, 2.1 \mathrm{~mm} \times 100 \mathrm{~mm})$ and the temperature of column was $30^{\circ} \mathrm{C}$. The mobile phase was composed of solvent A $(0.1 \%$ formic acid in water) and B $(0.1 \%$ formic acid in acetonitrile) at a constant flow rate of $0.2 \mathrm{~mL} / \mathrm{min}$. The gradient was programmed to increase the amount of solvent B from an initial $5 \%$ (maintained for $0.25 \mathrm{~min}$ ) to $20 \%$ in $2 \mathrm{~min}$, stabilize at $20 \%$ for $8 \mathrm{~min}$, and then to $95 \%$ in $15 \mathrm{~min}$ (maintained for $1.0 \mathrm{~min}$ ) then return to the initial conditions $(5 \% \mathrm{~B})$ in $1.0 \mathrm{~min}$. The mass spectrometer was operated at electrospray ionization mode (ESI) and performed MS1 scan, the scan ranged from $m / z 50$ to 400 . Positive and negative polarity modes were used simultaneously during the same analytical run. Desolation $\left(400^{\circ} \mathrm{C}\right)$ and ion source $\left(150^{\circ} \mathrm{C}\right)$ were kept at constant temperatures. The voltage was $1000 \mathrm{~V}$ and $20 \mathrm{~V}$ of capillary and cone, respectively. According to the results of MS1 scan, high responses of molecular ions were found out, and then performed MS2 scan. Scanning range was 50-200 m/z. Argon (purity $>99.999 \%$ ) was used as the collision gas at a constant flow of $0.16 \mathrm{~mL} / \mathrm{min}$. The metabolites were presumed by the molecular ion and the characteristic fragment ion peaks of the MS2.

\subsection{Degradation of Chlorpyrifos by Crude Enzyme}

Strain $X 1^{\mathrm{T}}\left(\mathrm{OD}_{600}=0.6,1 \mathrm{~mL}\right)$ was added to $1 \mathrm{~L} \mathrm{LB}$ medium and incubated at $150 \mathrm{rpm}$ and $37^{\circ} \mathrm{C}$ for $12 \mathrm{~h}$. The cells were harvested by centrifugation $(6000 \times \mathrm{g}$ for $10 \mathrm{~min})$ at $4{ }^{\circ} \mathrm{C}$ and washed twice with phosphate buffer ( $50 \mathrm{mM}, \mathrm{pH}$ 7.0). The washed cells were resuspended in $25 \mathrm{~mL}$ phosphate buffer and disrupted by ultrasonic homogenizer at $250 \mathrm{~W}$ by working for $5 \mathrm{~s}$ and stopping for $5 \mathrm{~s}, 100$ times. The crude enzyme was extracted by centrifugation at $12,000 \times \mathrm{g}$ for $10 \mathrm{~min}$. The concentration of crude enzyme was detected by Nanodrop One (BioRad, Hercules, CA, USA). The activity of crude enzyme was measured by detecting the degradation of chlorpyrifos. A standard tube was contained $50 \mathrm{mg} / \mathrm{L}$ chlorpyrifos, $1 \mathrm{mg} / \mathrm{L}$ crude enzyme in phosphate buffer and incubated at constant temperature $\left(37^{\circ} \mathrm{C}\right)$. The negative control was without enzyme under the same condition. The tubes were periodically sampled and the residual of chlorpyrifos was detected by the UPLC method. 


\subsection{Calculation and Statistical Analysis}

The data calculation and statistical analysis were performed by Origin 8.0 software (Origin Lab Corp., Northampton, MA, USA) and SPSS 20.0 software (IBM, Armonk, NY, USA). The degradation rate was calculated from the following equation:

$$
\text { Degradation rate }(\%)=\frac{C_{0}-C_{t}}{C_{0}} \times 100 \%
$$

The degradation curve was fitted with the first order kinetic equation $\ln \frac{C_{t}}{C_{0}}=k t$. The degradation $\mathrm{t}_{1 / 2}$ was $\mathrm{t}_{1 / 2}=\ln 2 / \mathrm{k}$, where $C_{0}, C_{t}, k$ are the initial concentration, treatment residual concentration and rate constant, respectively.

\section{Results}

\subsection{Effects of Inoculation Volume on Chlorpyrifos Degradation by Strain $X 1^{T}$}

As shown in Figure 1A. After $8 \mathrm{~h}$ incubation, the degradation rates of $50 \mathrm{mg} / \mathrm{L}$ chlorpyrifos were $10.6 \%, 26.4 \%, 69.1 \%$ and $85.2 \%$ with the cell suspension volumes of strain $\mathrm{X} 1^{\mathrm{T}}$ range from $1 \%, 2 \%, 5 \%$ and $10 \%$, respectively. After $12 \mathrm{~h}$ incubation, the degradation rates were increased to $14 \%, 36.7 \%, 74.5 \%$ and $95 \%$. Under the condition of $10 \%$ inoculation volume of strain $\mathrm{X} 1^{\mathrm{T}}, 50 \mathrm{mg} / \mathrm{L}$ chlorpyrifos was nearly complete degraded within $12 \mathrm{~h}$. However, when the inoculation volume was increased to $20 \%$, the degradation rate was not continues increased. The degradation percentage of chlorpyrifos showed no significant difference $(p<0.05)$ under the condition of $10 \%$ or $20 \%$ inoculation volume after 8 and $12 \mathrm{~h}$. It was shown that the strain $\mathrm{X} 1^{\mathrm{T}}$ had reached saturation under the condition of $10 \%$ inoculation volume and further increased the inoculation volume could not improve the degradation efficiency. This indicated that the optimum inoculation volume was $10 \%$.

\subsection{Effects of $\mathrm{pH}$ on Chlorpyrifos Degradation by Strain $\mathrm{X} 1^{T}$}

The degradation of $20 \mathrm{mg} / \mathrm{L}$ chlorpyrifos under different $\mathrm{pH}(5,6,7,8$ and 9$)$ by strain $\mathrm{X} 1^{\mathrm{T}}$ were shown in Figure 1B. In the $\mathrm{pH}$ range from 5 to 9 , strain $\mathrm{X} 1^{\mathrm{T}}$ always shows good degradation activity and the degradation rates were $33.5 \pm 1.07,59.2 \pm 0.73,94.7 \pm 0.06,94.6 \pm 0.21$ and $96.7 \pm 0.19$, respectively, after $12 \mathrm{~h}$ incubation. These results suggest that chlorpyrifos is more difficult to degrade under acidic conditions. Meanwhile, there was no significant difference $(p<0.05)$ in the degradation effect of chlorpyrifos under alkaline conditions ( $\mathrm{pH} 7$ to 9 ). These results indicated that the optimum $\mathrm{pH}$ range for chlorpyrifos degradation by $\mathrm{X} 1^{\mathrm{T}}$ was $5-9$.

\subsection{Effects of Temperature on Chlorpyrifos Degradation by Strain $X 1^{T}$}

The degradation of $20 \mathrm{mg} / \mathrm{L}$ chlorpyrifos by strain $X 1^{\mathrm{T}}$ at different temperatures $\left(20-47^{\circ} \mathrm{C}\right)$ is shown in Figure 1C. The degradation rates of chlorpyrifos were $50.3 \pm 2.64,79.5 \pm 0.18,94.5 \pm 0.32$, $89.5 \pm 1.14$ and $14.4 \pm 1.07$, respectively, after $12 \mathrm{~h}$ incubation in MSM and the degradation activity of strain $X 1^{\mathrm{T}}$ increased with the increase of temperature $\left(20-42^{\circ} \mathrm{C}\right)$. However, it significantly reduced to $14.4 \%$ at $47^{\circ} \mathrm{C}$. These results suggested that the optimum temperature for chlorpyrifos degradation was $30-42^{\circ} \mathrm{C}$. 

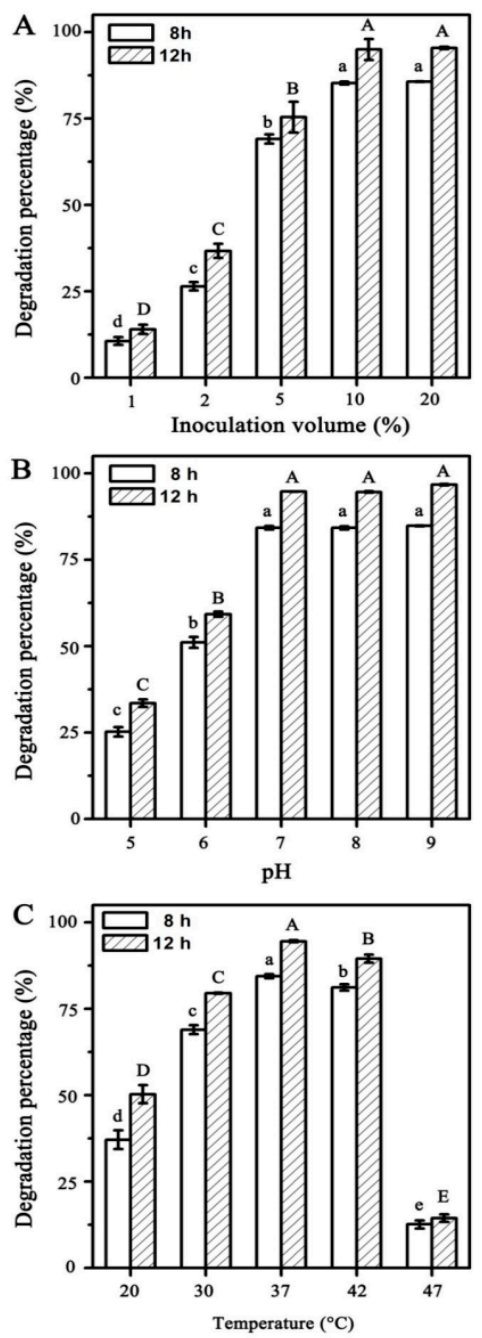

Figure 1. Effects of inoculation volume (A), temperature $(\mathbf{B})$ and $\mathrm{pH}(\mathbf{C})$ on chlorpyrifos degradation by strain $X 1^{\mathrm{T}}$ in 8 and $12 \mathrm{~h}$. (A) The effects of inoculation volumes on the biodegradation of chlorpyrifos at level of $1-20 \%$ under the condition of $37^{\circ} \mathrm{C}$ and $\mathrm{pH}$ 7. (B) The effects of temperature on chlorpyrifos degradation at $20-47^{\circ} \mathrm{C}$ under the condition of $10 \%$ inoculation volumes and $\mathrm{pH} 7$. (C) The effects of $\mathrm{pH}$ on the biodegradation of chlorpyrifos at 5-9 under the condition of $10 \%$ inoculation volumes and $37^{\circ} \mathrm{C}$. All values are means \pm standard deviation of triplicate measurements. Mean values with the same letter ( $a, b, c, d$, e or A, B, C, D, E) are not significantly different with reaction time ( 8 or 12 h) by LSD at the $5 \%$ level.

\subsection{Degradation Kinetics of Chlorpyrifos by Strain $X 1^{T}$}

Optimum conditions $\left(10 \%\right.$ inoculation volume, $\mathrm{pH} 7$ and $\left.37^{\circ} \mathrm{C}\right)$ were applied to detect the degradation of chlorpyrifos at different initial concentrations $(20,200$ and $500 \mathrm{mg} / \mathrm{L})$. When the initial concentrations were 20, 200 and $500 \mathrm{mg} / \mathrm{L}$, the degradation rates of chlorpyrifos were $100 \%, 100 \%$ and $90 \%$ within $48 \mathrm{~h}$ (Figure 2). The degradation curves were well fitted with first-order kinetics and the coefficient $\mathrm{R}^{2}$ were $0.9612,0.9003$ and 0.9795 , respectively (Table 1 ). From the degradation rate constant $(\mathrm{K})$, it can be seen that the activity of strain $\mathrm{X} 1^{\mathrm{T}}$ gradually decreases with the increase of the initial concentration of chlorpyrifos. The reason was that the main metabolite of chlorpyrifos, TCP, was toxic to the bacteria. When the degradation rate of TCP was lower than the production rate, TCP would gradually accumulate in the medium and affect the degradation of chlorpyrifos. The minimum inhibitory concentration (MIC) of chlorpyrifos and TCP to strain $\mathrm{X} 1^{\mathrm{T}}$ were also detected by MSM gradient plate. The results showed that the MIC of TCP to strain $X 1^{\mathrm{T}}$ was $22.3 \pm 1.0 \mathrm{mg} / \mathrm{L}$. However, $500 \mathrm{mg} / \mathrm{L}$ chlorpyrifos gradient plate cannot detect its bactericidal activity against strain $\mathrm{X} 1^{\mathrm{T}}$. 
These results further indicate that the decrease of degradation kinetics constants was caused by the metabolite TCP. When the concentration of TCP exceeded the MIC, the degradation activity of strain $\mathrm{X} 1^{\mathrm{T}}$ would be inhibited.
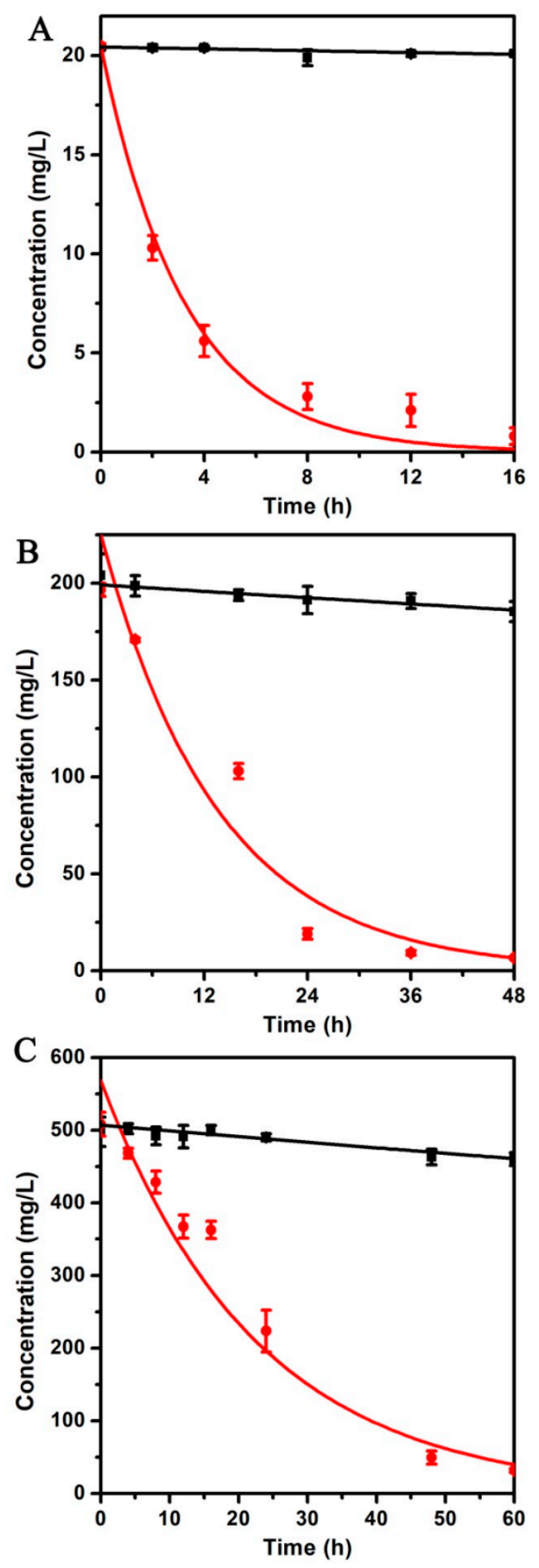

Figure 2. Degradation kinetics of chlorpyrifos with different initial concentration by strain $\mathrm{X} 1^{\mathrm{T}}$. (A) $20 \mathrm{mg} / \mathrm{L}$, (B) $200 \mathrm{mg} / \mathrm{L}$, (C) $500 \mathrm{mg} / \mathrm{L}$. The black line is the negative control (chlorpyrifos without strain $X 1^{\mathrm{T}}$ ) and the red line is the positive control (chlorpyrifos with strain $\mathrm{X} 1^{\mathrm{T}}$ ). All values are means \pm standard deviation of triplicate measurements. 
Table 1. Kinetic parameters for degradation of chlorpyrifos by C. nantongensis $\mathrm{X} 1^{\mathrm{T}}$.

\begin{tabular}{|c|c|c|c|c|}
\hline Compound & Concentration $(\mathrm{mg} / \mathrm{L})$ & Degradation Kinetics Equation & $\mathbf{k}$ & Half-Life $T_{1 / 2}(h)$ \\
\hline \multirow{3}{*}{ Chlorpyrifos } & 20 & $\begin{array}{c}C_{t}=20.49 e^{-0.308 t} \\
R^{2}=0.9612\end{array}$ & 0.308 & 2.25 \\
\hline & 200 & $\begin{array}{c}C_{t}=238.02 e^{-0.071 t} \\
R^{2}=0.9003\end{array}$ & 0.071 & 9.76 \\
\hline & 500 & $\begin{array}{c}C_{t}=568.20 e^{-0.044 t} \\
R^{2}=0.9795\end{array}$ & 0.044 & 15.75 \\
\hline
\end{tabular}

\subsection{Epression of opdB by RT-qPCR}

The expression of degradation gene (opdB) in chlorpyrifos degradation process was determined by the relative quantitation method with reference gene (rpoB) (Figure 3). Compared with the expression at $0 \mathrm{~h}$, the expression of opdB gradually increased and reached maximum at $12 \mathrm{~h}$ as the reaction progressed to indicate that chlorpyrifos could induce the expression of degradation enzyme.

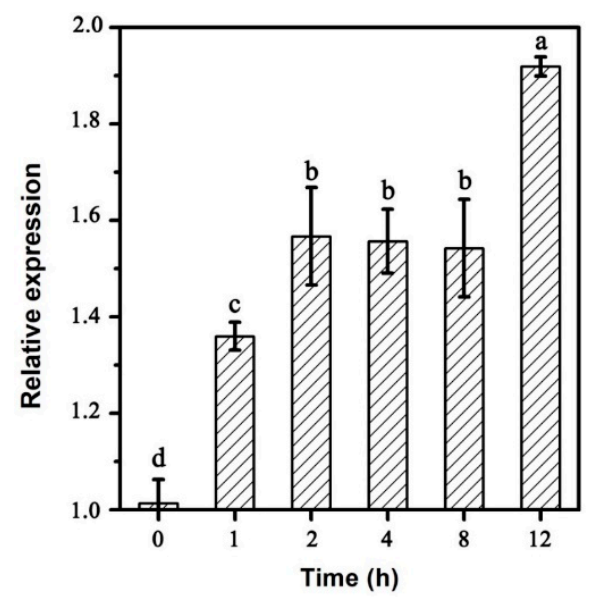

Figure 3. Relative normalized expression of degradation gene (opdB) in degradation process. All values are means \pm standard deviation of triplicate measurements. Mean values with the same letter (a, b, $c$ and d) are not significantly different among reaction time ( 0 to $12 \mathrm{~h}$ ) by LSD at the $5 \%$ level.

\subsection{Metabolites and Degradation Pathways of Chlorpyrifos by Strain $X 1^{T}$}

The metabolic products of chlorpyrifos were measured and analyzed by UPLC-MS/MS. Seven metabolites (M1 to M7, Figure 4, Table 2) were detected. 

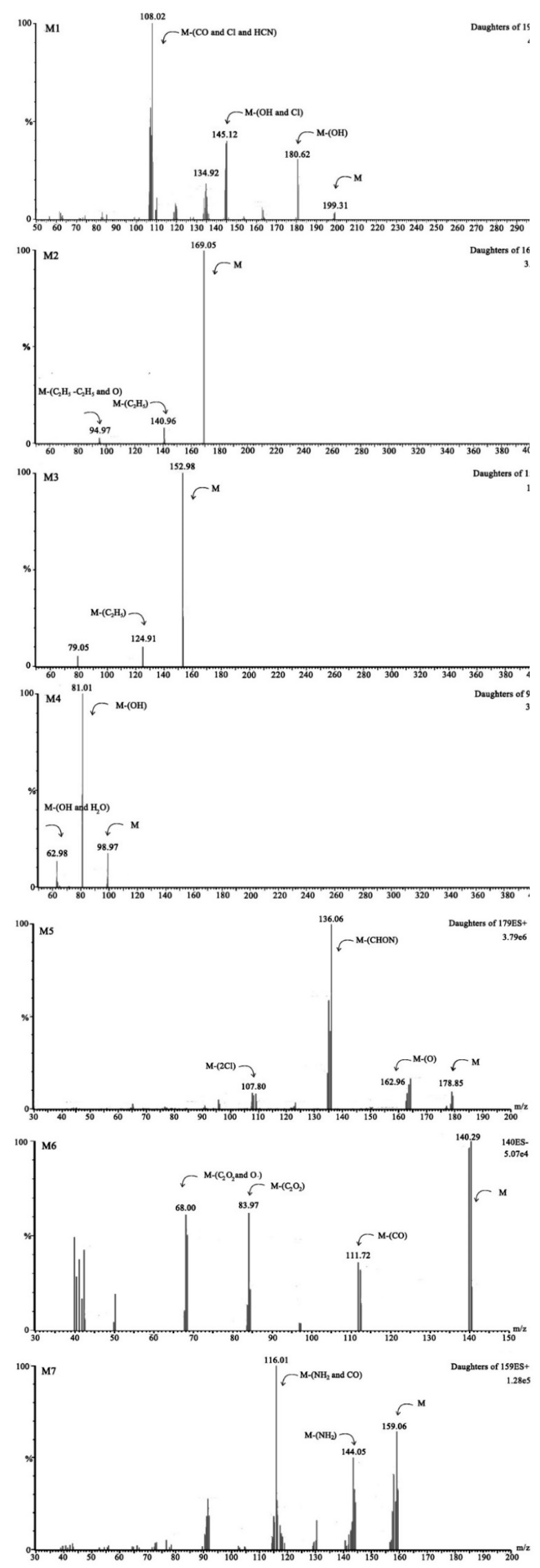

Figure 4. LC-MS/MS analysis of metabolites in the degradation process. (M1) TCP, (M2) DETP, (M3) DEP, (M4) H3PO4, (M5) DCPD, (M6) DHPD, (M7) ATOPA. 
The prominent protonated $[\mathrm{M}+1]^{+}$molecular ion of $\mathrm{M} 1$ was observed at $\mathrm{m} / \mathrm{z} 199.31$, and it was identified as TCP by comarison with a standard. The second metabolite of M2 was identified as diethylthiophosphoric acid (DETP) which showed a molecular ion at $\mathrm{m} / \mathrm{z} 169.05[\mathrm{M}-1]^{-}$, and fragment ions at $140.95[\mathrm{M}-29]^{-}$and $94.97[\mathrm{M}-74]^{-}$, indicating losses of $\mathrm{H}, \mathrm{C}_{2} \mathrm{H}_{5}$ and $\mathrm{C}_{2} \mathrm{H}_{5}+\mathrm{C}_{2} \mathrm{H}_{5}+\mathrm{O}$. As previously reported M1 and M2 are the main metabolites of chlorpyrifos in hydrolysis processes. Meanwhile, M1 and M2 could be further metabolized into M3, M4, M5, M6 and M7 in strain X1 ${ }^{\mathrm{T}}$. The degradation product of M3 was identified as diethylacidphosphate (DEP) with a molecular ion at $\mathrm{m} / \mathrm{z}$ $152.98[\mathrm{M}-1]^{-}$and a $\mathrm{m} / \mathrm{z} 124.91$ [M - 29] $]^{-}$, peak, indicating losses of $\mathrm{H}$ and $\mathrm{C}_{2} \mathrm{H}_{5}$. The metabolite of M3 could be further metabolized into $\mathrm{M} 4$ which was identified as $\mathrm{H}_{3} \mathrm{PO}_{4}$. For TCP degradation, the product M5, with a molecular ion at $m / z 162.96[\mathrm{M}-16]^{+}$, and peaks at $136.06[\mathrm{M}-43]^{+}$and 107.80 $[\mathrm{M}-71]^{+}$indicating losses of $\mathrm{O}, \mathrm{CHON}$ and $2 \mathrm{Cl}$ was identified as 3,6-dichloro-2,5-dihydroxypyridine (DCPD). M5 could be further dechlorinated by strain $\mathrm{X} 1^{\mathrm{T}}$ to produce M6, which was identified as 3,6-dihydroxypyridine-2,5-dione (DHPD) and showed a molecular ion at $\mathrm{m} / \mathrm{z} 111.72$ [M-28] $]^{-}$, and peaks at $\mathrm{m} / \mathrm{z} 83.97$ [M-56] $^{-}$and 68.00 [M-72] $^{-}$, indicating losses of $\mathrm{CO}, \mathrm{C}_{2} \mathrm{O}_{2}, \mathrm{C}_{2} \mathrm{O}_{2}$ and $\mathrm{O}$. The discovery of $\mathrm{M} 5$ and $\mathrm{M} 6$ indicated that the degradation process of TCP in strain $\mathrm{X} 1^{\mathrm{T}}$ was a stepwise dechlorination process and all three chlorine atoms on TCP could be removed. The ring opening product of 5-amino-2,4,5-trioxopentanoic acid (M7, ATOPA) with a molecular ion at $\mathrm{m} / \mathrm{z} 159.06$ [M-1] $]^{+}$, and peaks at $143.64[\mathrm{M}-16]^{+}, 116.01[\mathrm{M}-44]^{+}$, indicating losses of $\mathrm{H}, \mathrm{NH}_{2}$ and $\mathrm{CO} 2$, was also detected in the samples. According to the KEGG database, M7 could be converted to maleyl acetate and $\beta$-ketoadipate in bacteria, which could enter the tricarboxylic acid cycle and eventually be completely metabolized into carbon dioxide and water. The degradation pathway of chlorpyrifos in strain $\mathrm{X} 1^{\mathrm{T}}$ is shown in Figure 5.

Table 2. Analysis of metabolites of chlorpyrifos in strain $\mathrm{X} 1^{\mathrm{T}}$ by LC-MS/MS.

\begin{tabular}{ccccc}
\hline Metabolites & \multicolumn{2}{c}{$\begin{array}{c}\text { Compounds and Molecular } \\
\text { Weight }(\mathbf{a m u})\end{array}$} & $\begin{array}{c}\text { Molecular } \\
\text { Ions }(\mathbf{m} / \mathbf{z})\end{array}$ & Major Fragments $(\mathbf{m} / \mathbf{z})$ \\
\hline M1 & TCP & 198.43 & 199.31 & $181[\mathrm{M}-\mathrm{OH}], 145[\mathrm{M}-\mathrm{Cl}-\mathrm{OH}], 108[\mathrm{M}-\mathrm{Cl}-\mathrm{CO}-\mathrm{HCN}]$ \\
M2 & DETP & 170.17 & 169.05 & $141\left[\mathrm{M}-\mathrm{C}_{2} \mathrm{H}_{5}\right], 95\left[\mathrm{M}-\mathrm{C}_{2} \mathrm{H}_{5}-\mathrm{C}_{2} \mathrm{H}_{5}-\mathrm{O}\right]$ \\
M3 & DEP & 154.10 & 152.98 & $125\left[\mathrm{M}-\mathrm{C}_{2} \mathrm{H}_{5}\right]$ \\
M4 & $\mathrm{H}_{3} \mathrm{PO}_{4}$ & 98.00 & 98.97 & $81[\mathrm{M}-\mathrm{OH}], 63\left[\mathrm{M}-\mathrm{OH}-\mathrm{H}_{2} \mathrm{O}\right]$ \\
M5 & DCPD & 180.00 & 178.85 & $163[\mathrm{M}-\mathrm{O}], 136[\mathrm{M}-\mathrm{CHON}], 108[\mathrm{M}-2 \mathrm{Cl}]$ \\
M6 & DHPD & 141.08 & 140.29 & $112[\mathrm{M}-\mathrm{CO}], 84\left[\mathrm{M}-\mathrm{C}_{2} \mathrm{O}_{2}\right], 68\left[\mathrm{M}-\mathrm{C}_{2} \mathrm{O}_{2}-\mathrm{O}\right]$ \\
M7 & ATOPA & 159.10 & 159.06 & $144\left[\mathrm{M}-\mathrm{NH}_{2}\right], 116\left[\mathrm{M}_{-}-\mathrm{NH}_{2}-\mathrm{CO}\right]$, \\
\hline
\end{tabular}

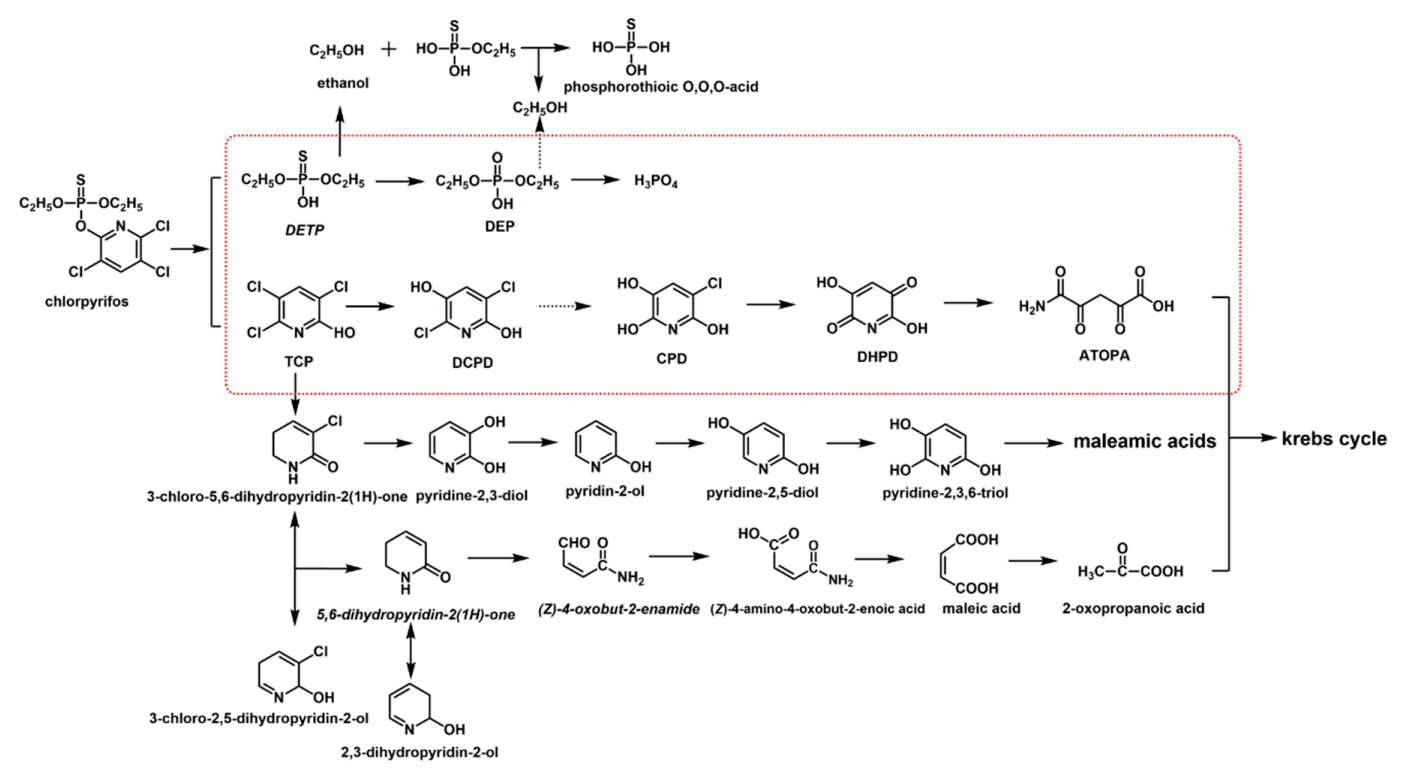

Figure 5. Degradation pathways of chlorpyrifos in strain $\mathrm{X} 1^{\mathrm{T}}$ and other bacteria. The degradation pathway of strain $\mathrm{X} 1^{\mathrm{T}}$ is shown in the red frame. 


\subsection{Degradation Activity of Crude Enzyme}

To further verify the degradation process, the crude enzyme was extracted. As shown in Figure 6, the crude enzyme extracted from strain $X 1^{\mathrm{T}}$ could also degrade $50 \mathrm{mg} / \mathrm{L}$ chlorpyrifos. However, the degradation ability of crude enzyme was not all as good as $(\sim 75 \%)$ strain $X 1^{\mathrm{T}}$ for the same bacterial quantity $\left(\mathrm{OD}_{600}=0.6\right)$.

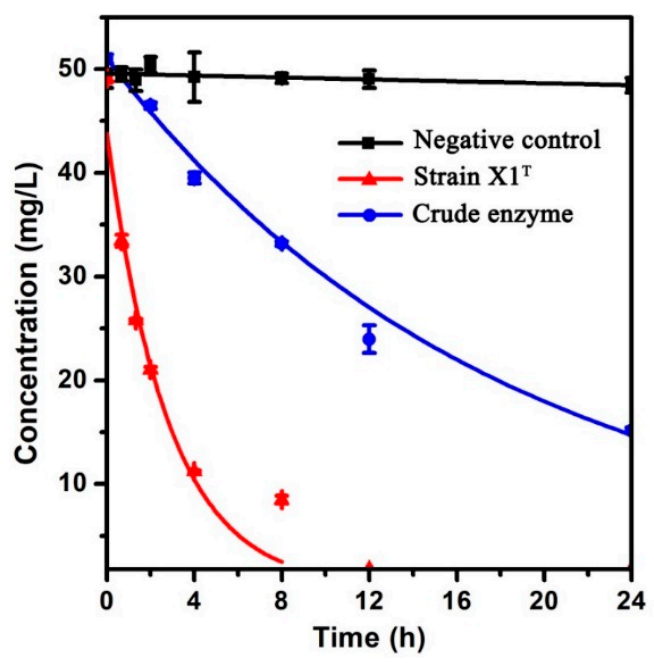

Figure 6. Degradation of $50 \mathrm{mg} / \mathrm{L}$ chlorpyrifos by strain X1T and crude enzyme.

\section{Discussion}

In this study, a high efficient chlorpyrifos-degrading strain, Cupriavidus nantongensis $\mathrm{X} 1^{\mathrm{T}}$, was reported. It can use chlorpyrifos as a sole carbon source. A variety of microorganisms capable of degrading chlorpyrifos have been isolated from the environment and identified (Table 3). However, only a few strains (Paracoccus sp. TRP [13], Cladosporium cladosporioides Hu-01 [28], Sphingomonas sp. DSP2 [14] and Bacillus pumilus C2A1 [29]) can both biodegrade chlorpyrifos and TCP, but with limited degradation rates. They can take $48-360 \mathrm{~h}$ to completely degrade $50-100 \mathrm{mg} / \mathrm{L}$ chlorpyrifos and TCP $[20,30]$. Compared with these degradation strains, strain $\mathrm{X} 1^{\mathrm{T}}$ can degrade chlorpyrifos and TCP simultaneously with high degradation activity.

Table 3. Degradation rates of strain $\mathrm{X} 1^{\mathrm{T}}$ and other chlorpyrifos-degrading microorganisms.

\begin{tabular}{ccccc}
\hline Strains & $\begin{array}{c}\text { Initial Concentration } \\
\left(\mathbf{m g} \cdot \mathbf{L}^{\mathbf{- 1}} \mathbf{)}\right.\end{array}$ & Time (day) & Degradation (\%) & References \\
\hline C. nantongensis.X1 ${ }^{\mathrm{T}}$ & 20 & 0.67 & 100 & This study \\
C. nantongensis.X1 $^{\mathrm{T}}$ & 200 & 2 & 100 & This study \\
C. nantongensis.X1 $^{\mathrm{T}}$ & 500 & 2 & 90 & This study \\
Synechocystis sp. PUPCCC 64 & 5 & 5 & 93.8 & {$[31]$} \\
Flavobacterium sp.TCC27551 $_{\text {Enterobacter B-14 }}$ & 10 & 2 & 100 & {$[32]$} \\
C. cladosporioides Hu-01 & 50 & 3 & 100 & {$[28]$} \\
B. cereus MCAS02 & 50 & 5 & 100 & {$[33]$} \\
Streptomyces sp. AC5 & 50 & 7 & 89 & {$[34]$} \\
Paracoccus sp. TRP & 50 & 1 & 90 & {$[35]$} \\
A. faecalisDSP3 & 100 & 12 & 100 & {$[36]$} \\
Sphingobacterium sp. JAS3 & 300 & 5 & 100 & {$[28]$} \\
Alcaligenes sp. JAS1 & 300 & 3 & 100 & {$[37]$} \\
\hline
\end{tabular}

The degradation rates of chlorpyrifos by strain $\mathrm{X} 1^{\mathrm{T}}$ increased in the temperature range from 20 to $37^{\circ} \mathrm{C}$. The degradation activity remained $90 \%$ at $42{ }^{\circ} \mathrm{C}$, but decreased significantly at $47^{\circ} \mathrm{C}$. The results indicate that strain $\mathrm{X} 1^{\mathrm{T}}$ can maintain an efficient degradation activity in a high-temperature environment 
$\left(37-42^{\circ} \mathrm{C}\right)$. This result is similar to the optimum growth temperature of strain $\mathrm{X} 1^{\mathrm{T}}$. Meanwhile, the degradation ability of the strain is mainly the function of the degradation enzymes in vivo, and the change of temperature will significantly affect the activity of the degradation enzymes [39]. Compared with the optimum temperatures of other organophosphorus hydrolases MPH, PTE and GPD, strain $\mathrm{X} 1^{\mathrm{T}}$ has a higher utilization value in actual chlorpyrifos-contaminated soil remediation [40-42].

Enterobacter sp. B-14 was reported to rapidly degrade chlorpyrifos under alkaline conditions, while the degradation rate of chlorpyrifos was notably reduced under acidic conditions, which was very similar to the results of strain $X 1^{\mathrm{T}}$ [43]. One of the main reasons is that organophosphorus insecticides are unstable and more easily hydrolyzed under alkaline conditions [44]. However, different from other degrading strains, strain $\mathrm{X}^{\mathrm{T}}$ not only maintains a high degradation activity, but also can tolerate an alkaline environment (the amount of bacteria remains the same).

Different substrate concentrations could also affect the degradation capacity of strain $\mathrm{X} 1^{\mathrm{T}}$. The kinetics results showed that the degradation kinetics constant $(\mathrm{k})$ decreased with the increase of substrate concentration (20-500 $\mathrm{mg} / \mathrm{L})$. The degradation kinetics constant at initial concentration of 20 $\mathrm{mg} / \mathrm{L}$ was 7 -fold higher than that of $500 \mathrm{mg} / \mathrm{L}$. One major reason is that TCP, the main metabolite of chlorpyrifos, is toxic and can inhibit the growth of bacteria [1].

Rt-qPCR results showed that the addition of chlorpyrifos could promote the expression of organophosphorus hydrolase (opdB) and with the gradual progress of chlorpyrifos degradation, the expression level gradually decreased. This indicates that organophosphorus hydrolase in strain $\mathrm{X} 1^{\mathrm{T}}$ is an inducible enzyme. Many organophosphorus degradation enzymes have been expressed and the structures were analyzed [45]. All these enzymes isolated so far were belonged to metal enzymes and have a bivalent cationic bimetallic activity center [25]. Different degrading enzymes have optimum substrates. Paraoxonase (with $\mathrm{Ca}^{2+}$ as metal ions activity center) displays a preference for sarin and soman [46], OP acid anhydrolase (with $\mathrm{Mn}^{2+}$ as metal ions activity center) displays a preference for tabun [47], phosphotriesterase (with $\mathrm{Zn}^{2+}$ as metal ions activity center) displays a preference for ethyl-substituted OPs and OP-degrading hydrolases (with $\mathrm{Co}^{2+}$ or $\mathrm{Cd}^{2+}$ as metal ions activity center) displays a preference for methyl-substituted OPs $[25,41]$. In present study, OpdB in strain $\mathrm{X} 1^{\mathrm{T}}$ belongs to OP-degrading hydrolases, which could degrade chlorpyrifos and had high degradation activity against methyl parathion, parathion, profenofos, methidathion and isocarbophos [20].

The proposed degradation pathway of chlorpyrifos by strain $X 1^{\mathrm{T}}$ is shown in Figure 5 . Chlorpyrifos was first hydrolyzed to DETP and TCP by OpdB. Then, DETP was oxidized to DEP, which was further degraded to ethanol and phosphoric acid. Meanwhile, TCP could be further degraded to 3,6-dihydroxy-2,5-diketone through stepwise oxidative dechlorination, and then the pyridine ring cleaved to form 5-amino-2,4,5-tricarbonylpentanoic acid, which finally mineralized to $\mathrm{CO}_{2}$ and $\mathrm{H}_{2} \mathrm{O}$ by the tricarboxylic acid cycle. This pathway is completely different from the reductive dechlorination pathway also shown in Figure 5. This oxidative dechlorination is similar to that previously reported for 2,4,6-trichlorophenol monooxygenase. However, due to the unstable structure and low content of the dechlorination products, the complete dechlorination process has not been determined. In this study, the complete dechlorination products (with one $-\mathrm{Cl}$, two $-\mathrm{Cl}$ and three $-\mathrm{Cl}$ removed) were simultaneously detected. Meanwhile, the tcpA gene (encoding 2,4,6-trichlorophenol monooxygenase) was found in chromosome 1 of strain $X 1^{\mathrm{T}}$ by the previous complete genome sequencing [17]. The optimum degradation substrate and degradation mechanism of 2,4,6-trichlorophenol monooxygenase needs to be further studied after expression and purification.

Chlorpyrifos is one of the pesticides with the highest residue detection rate in the environment. Less than $1 \%$ of chlorpyrifos is applied to the target organisms, and most of the rest ends up contaminating the atmosphere, soil and water. Microbial degradation is an efficient and inexpensive way to repair soil and water contaminated by chlorpyrifos. Most of the degrading strains were isolated from activated sludges and pesticide-contaminated soils and they use pesticides as their sole source of carbon and energy for growth. After the decontamination is completed, it is difficult for the degrading strains to continue to grow in the soil and further affect the indigenous microorganisms. In terms of safety issues, 
the virulence genes were analyzed in the Virulence Factors Database (VFDB) with complete genome sequence of strain $X 1^{\mathrm{T}}$. According to the similarity threshold of $80 \%$, no virulence genes were found in strain $X 1^{\mathrm{T}}$. Meanwhile, to further reduce the risk and effects in environment, it is a common method to take the degradation genes into non-pathogenic E. coli engineering bacteria and immobilized them in environmentally friendly materials.

\section{Conclusions}

A high efficient chlorpyrifos-degrading strain, Cupriavidus nantongensis $\mathrm{X} 1^{\mathrm{T}}$, was isolated and characterized. Strain $X 1^{\mathrm{T}}$ can tolerate high concentrations of chlorpyrifos under a wide range of temperatures and $\mathrm{pH}$ values. The metabolism of chlorpyrifos in strain $\mathrm{X1}^{\mathrm{T}}$ was a stepwise oxidative dechlorination and the metabolites can further ring-open to reduce the toxicity. The crude enzyme extracted from the strain $\mathrm{X} 1^{\mathrm{T}}$ still maintained good degradation activity. This finding provides a novel valuable material for the remediation in chlorpyrifos and other organophosphorus insecticidecontaminated soil and water.

Author Contributions: Data curation, H.Q.; Formal analysis, Y.C.; Project administration, R.H.; Resources, T.S.; Software, L.F.; Supervision, R.H.; Writing—original draft, T.S. and L.F.; Writing—review \& editing, L.F., X.W. and R.H.

Funding: This work was supported in part by grants from the National Key R\&D Program of China (2016YFD0200205), the National Natural Science Foundation of China (31471792, 31972314).

Conflicts of Interest: The authors declare no conflict of interest.

\section{References}

1. Yadav, M.; Shukla, A.K.; Srivastva, N.; Upadhyay, S.N.; Dubey, S.K. Utilization of microbial community potential for removal of chlorpyrifos: A review. Crit. Rev. Biotechnol. 2016, 36, 727-742. [CrossRef] [PubMed]

2. Feng, F.; Ge, J.; Li, Y.; Cheng, J.; Zhong, J.; Yu, X. Isolation, colonization, and chlorpyrifos degradation mediation of the endophytic bacterium Sphingomonas strain HJY in Chinese Chives (Allium tuberosum). J. Agric. Food Chem. 2017, 65, 1131-1138. [CrossRef] [PubMed]

3. Wang, D.; Singhasemanon, N.; Goh, K.S. A statistical assessment of pesticide pollution in surface waters using environmental monitoring data: Chlorpyrifos in Central Valley, California. Sci. Total Environ. 2016, 571, 332-341. [CrossRef] [PubMed]

4. Singh, B.K.; Walker, A.; Morgan, J.A.W.; Wright, D.J. Effects of soil pH on the biodegradation of chlorpyrifos and isolation of a chlorpyrifos-degrading bacterium. Appl. Environ. Microbiol. 2003, 69, 5198-5206. [CrossRef] [PubMed]

5. Stone, W.W.; Gilliom, R.J.; Ryberg, K.R. Pesticides in U.S. streams and rivers: Occurrence and trends during 1992-2011. Environ. Sci. Technol. 2014, 48, 11025-11030. [CrossRef] [PubMed]

6. Tuncel, S.G.; Oztas, N.B.; Erduran, M.S. Air and groundwater pollution in an agricultural region of the Turkish Mediterranean coast. J. Air Waste Manag. Assoc. 2008, 58, 1240-1249. [CrossRef] [PubMed]

7. Ismail, M.; Khan, Q.M.; Ali, R.; Ali, T.; Mobeen, A. Genotoxicity of chlorpyrifos in freshwater fish Labeo rohita using Alkaline Single-cell Gel Electrophoresis (Comet) assay. Drug Chem. Toxicol. 2014, 37, 466-471. [CrossRef]

8. Guo, J.; Zhang, J.; Wu, C.; Lv, S.; Lu, D.; Qi, X.; Jiang, S.; Feng, C.; Yu, H.; Liang, W.; et al. Associations of prenatal and childhood chlorpyrifos exposure with Neurodevelopment of 3-year-old children. Environ. Pollut. 2019, 251, 538-546. [CrossRef]

9. Affam, A.C.; Chaudhuri, M. Degradation of pesticides chlorpyrifos, cypermethrin and chlorothalonil in aqueous solution by $\mathrm{TiO}_{2}$ photocatalysis. J. Environ. Manag. 2013, 130, 160-165. [CrossRef]

10. Bootharaju, M.S.; Pradeep, T. Understanding the degradation pathway of the pesticide, chlorpyrifos by noble metal nanoparticles. Langmuir ACS J. Surf. Colloids 2012, 28, 2671-2679. [CrossRef]

11. Kumar, S.; Kaushik, G.; Dar, M.A.; Nimesh, S.; Lopez-Chuken, U.J.; Villarreal-Chiu, J.F. Microbial degradation of organophosphate pesticides: A review. Pedosphere 2018, 28, 190-208. [CrossRef] 
12. Zhang, Q.; Li, S.; Ma, C.; Wu, N.; Li, C.; Yang, X. Simultaneous biodegradation of bifenthrin and chlorpyrifos by Pseudomonas sp. CB2. J. Environ. Sci. Health Part B Pestic. Food Contam. Agric. Wastes 2018, 53, $304-312$. [CrossRef] [PubMed]

13. Li, K.; Wang, S.; Shi, Y.; Qu, J.; Zhai, Y.; Xu, L.; Xu, Y.; Song, J.; Liu, L.; Rahman, M.A.; et al. Genome sequence of Paracoccus sp. strain TRP, a chlorpyrifos biodegrader. J. Bacteriol. 2011, 193, 1786-1787. [CrossRef] [PubMed]

14. Li, X.; He, J.; Li, S. Isolation of a chlorpyrifos-degrading bacterium, Sphingomonas sp. strain Dsp-2, and cloning of the mpd gene. Res. Microbiol. 2007, 158, 143-149. [CrossRef] [PubMed]

15. Lu, P.; Li, Q.; Liu, H.; Feng, Z.; Yan, X.; Hong, Q.; Li, S. Biodegradation of chlorpyrifos and 3,5,6-trichloro-2-pyridinol by Cupriavidus sp. DT-1. Bioresour. Technol. 2013, 127, 337-342. [CrossRef]

16. Abraham, J.; Silambarasan, S. Biodegradation of chlorpyrifos and its hydrolysis product 3,5,6-trichloro-2-pyridinol using a novel bacterium Ochrobactrum sp. JAS2: A proposal of its metabolic pathway. Pestic. Biochem. Physiol. 2016, 126, 13-21. [CrossRef]

17. Lei, W.J.; Zhou, X.Y. Experiment and simulation on adsorption of 3,5,6-trichloro-2-pyridinol in typical farmland of purple soil, Southwestern China. Soil Sediment Contam. 2017, 26, 345-363. [CrossRef]

18. Dores, E.F.G.C.; Spadotto, C.A.; Weber, O.L.S.; Villa, R.D.; Vecchiato, A.B.; Pinto, A.A. Environmental behavior of chlorpyrifos and endosulfan in a tropical soil in Central Brazil. J. Agric. Food Chem. 2016, 64, 3942-3948. [CrossRef]

19. Caceres, T.; He, W.X.; Naidu, R.; Meharaj, M. Toxicity of chlorpyrifos and TCP alone and in combination to Daphnia carinata: The influence of microbial degradation in natural water. Water Res. 2007, 41, 4497-4503. [CrossRef]

20. Fang, L.; Shi, T.; Chen, Y.; Wu, X.; Zhang, C.; Tang, X.; Li, Q.X.; Hua, R. Kinetics and catabolic pathways of the insecticide chlorpyrifos, annotation of the degradation genes, and characterization of enzymes TcpA and Fre in Cupriavidus nantongensis $\mathrm{X} 1^{\mathrm{T}}$. J. Agric. Food Chem. 2019, 67, 2245-2254. [CrossRef]

21. Feng, Y.; Racke, K.D.; Bollag, J. Isolation and characterization of a chlorinated-pyridinol-degrading bacterium. Appl. Environ. Microbiol. 1997, 63, 4096-4098.

22. Cao, L.; Xu, J.H.; Wu, G.; Li, M.X.; Jiang, J.D.; He, J.; Li, S.P.; Hong, Q. Identification of two combined genes responsible for dechlorination of 3,5,6-trichloro-2-pyridinol (TCP) in Cupriavidus pauculus P2. J. Hazard. Mater. 2013, 260, 700-706. [CrossRef]

23. Anspaugh, D.D.; Roe, R.M. Assays for the classification of two types of esterases: Carboxylic ester hydrolases and phosphoric triester hydrolases. Curr. Protoc. Toxicol. 2002, 13, 4-10.

24. van Dyk, J.S.; Pletschke, B. Review on the use of enzymes for the detection of organochlorine, organophosphate and carbamate pesticides in the environment. Chemosphere 2011, 82, 291-307. [CrossRef]

25. Schenk, G.; Mateen, I.; Ng, T.K.; Pedroso, M.M.; Mitic, N.; Jafelicci, M.; Marques, R.F.C.; Gahan, L.R.; Ollis, D.L. Organophosphate-degrading metallohydrolases: Structure and function of potent catalysts for applications in bioremediation. Coord. Chem. Rev. 2016, 317, 122-131. [CrossRef]

26. Fang, L.C.; Chen, Y.F.; Zhou, Y.L.; Wang, D.S.; Sun, L.N.; Tang, X.Y.; Hua, R.M. Complete genome sequence of a novel chlorpyrifos degrading bacterium, Cupriavidus nantongensis X1. J. Biotechnol. 2016, 227, 1-2. [CrossRef]

27. Sun, L.-N.; Wang, D.-S.; Yang, E.-D.; Fang, L.-C.; Chen, Y.-F.; Tang, X.-Y.; Hua, R.-M. Cupriavidus nantongensis sp. nov., a novel chlorpyrifos-degrading bacterium isolated from sludge. Int. J. Syst. Evol. Microbiol. 2016, 66, 2335-2341. [CrossRef]

28. Chen, S.; Liu, C.; Peng, C.; Liu, H.; Hu, M.; Zhong, G. Biodegradation of chlorpyrifos and its hydrolysis product 3,5,6-trichloro-2-pyridinol by a new fungal strain Cladosporium cladosporioides Hu-01. PLoS ONE 2012, 7, e47205. [CrossRef]

29. Anwar, S.; Liaquat, F.; Khan, Q.M.; Khalid, Z.M.; Iqbal, S. Biodegradation of chlorpyrifos and its hydrolysis product 3,5,6-trichloro-2-pyridinol by Bacillus pumilus strain C2A1. J. Hazard. Mater. 2009, 168, 400-405. [CrossRef]

30. Gilani, R.A.; Rafique, M.; Rehman, A.; Munis, M.F.H.; Rehman, S.U.; Chaudhary, H.J. Biodegradation of chlorpyrifos by bacterial genus Pseudomonas. J. Basic Microbiol. 2016, 56, 105-119. [CrossRef]

31. Singh, D.P.; Nadda, J.; Singh, Y.; Garg, A.; Kaur, N.; Gulati, A. Chlorpyrifos degradation by the cyanobacterium Synechocystis sp. strain PUPCCC 64. Environ. Sci. Pollut. Res. 2011, 18, 1351-1359. [CrossRef] 
32. Mallick, K.; Bharati, K.; Banerji, A.; Shakil, N.A.; Sethunathan, N. Bacterial degradation of chlorpyrifos in pure cultures and in soil. Bull. Environ. Contam. Toxicol. 1999, 62, 48-54. [CrossRef]

33. Duraisamy, K.; Muthusamy, S.; Balakrishnan, S. An eco-friendly detoxification of chlorpyrifos by Bacillus cereus MCAS02 native isolate from agricultural soil, Namakkal, Tamil Nadu, India. Biocatal. Agric. Biotechnol. 2018, 13, 283-290. [CrossRef]

34. Briceño, G.; Fuentes, M.S.; Palma, G.; Jorquera, M.A.; Amoroso, M.J.; Diez, M.C. Chlorpyrifos biodegradation and 3,5,6-trichloro-2-pyridinol production byactinobacteria isolated from soil. Int. Biodeterior. Biodegrad. 2012, 73, 1-7. [CrossRef]

35. Xu, G.; Zheng, W.; Li, Y.; Wang, S.; Zhang, J.; Yan, Y. Biodegradation of chlorpyrifos and 3,5,6-trichloro-2-pyridinol by a newly isolated Paracoccus sp. strain TRP. Int. Biodeter. Biodegr. 2008, 62, 51-56. [CrossRef]

36. Yang, L.; Zhao, Y.H.; Zhang, B.X.; Yang, C.H.; Zhang, X. Isolation and characterization of a chlorpyrifos and 3,5,6-trichloro-2-pyridinol degrading bacterium. FEMS Microbiol. Lett. 2010, 251, 67-73. [CrossRef]

37. Abraham, J.; Silambarasan, S. Biodegradation of chlorpyrifos and its hydrolyzing metabolite 3,5,6-trichloro-2-pyridinol by Sphingobacterium sp. JAS3. Process Biochem. 2013, 48, 1559-1564. [CrossRef]

38. Silambarasan, S.; Abraham, J. Kinetic studies on enhancement of degradation of chlorpyrifos and its hydrolyzing metabolite TCP by a newly isolated Alcaligenes sp. JAS1. J. Taiwan Inst. Chem. Eng. 2013, 44, 438-445. [CrossRef]

39. Yang, L.L.; Yang, X.; Li, G.B.; Fan, K.G.; Yin, P.F.; Chen, X.G. An integrated molecular docking and rescoring method for predicting the sensitivity spectrum of various serine hydrolases to organophosphorus pesticides. J. Sci. Food Agric. 2016, 96, 2184-2192. [CrossRef]

40. Li, Y.; Yang, H.; Xu, F. Identifying and engineering a critical amino acid residue to enhance the catalytic efficiency of Pseudomonas sp. methyl parathion hydrolase. Appl. Microbiol. Biotechnol. 2018, 102, 6537-6545. [CrossRef]

41. Pedroso, M.M.; Ely, F.; Mitic, N.; Carpenter, M.C.; Gahan, L.R.; Wilcox, D.E.; Larrabee, J.L.; Ollis, D.L.; Schenk, G. Comparative investigation of the reaction mechanisms of the organophosphate-degrading phosphotriesterases from Agrobacterium radiobacter (OpdA) and Pseudomonas diminuta (OPH). J. Biol. Inorg. Chem. 2014, 19, 1263-1275. [CrossRef]

42. Sharma, G.; Hu, Q.Y.; Jayasinghe-Arachchige, V.M.; Paul, T.J.; Schenk, G.; Prabhakar, R. Investigating coordination flexibility of glycerophosphodiesterase (GpdQ) through interactions with mono-, di-, and triphosphoester (NPP, BNPP, GPE, and paraoxon) substrates. Phys. Chem. Chem. Phys. 2019, 21, 5499-5509. [CrossRef]

43. Singh, B.K.; Walker, A.; Morgan, J.A.; Wright, D.J. Biodegradation of chlorpyrifos by enterobacter strain B-14 and its use in bioremediation of contaminated soils. Appl. Environ. Microbiol. 2004, 70, 4855-4863. [CrossRef]

44. Cortes-Eslava, J.; Gomez-Arroyo, S.; Risueno, M.C.; Testillano, P.S. The effects of organophosphorus insecticides and heavy metals on DNA damage and programmed cell death in two plant models. Environ. Pollut. 2018, 240, 77-86. [CrossRef]

45. Musilek, K.; Dolezal, M.; Gunn-Moore, F.; Kuca, K. Design, evaluation and structure-activity relationship studies of the AChE reactivators against organophosphorus pesticides. Med. Res. Rev. 2011, 31, 548-575. [CrossRef]

46. Jiang, X.L.; Li, M.; Zhou, J.G.; Yang, Q.B.; Du, L.J.; Du, J. Plasma paraoxonase-1, oxidized low-density lipoprotein and lipid peroxidation levels in gout patients. Cell Biochem. Biophys. 2011, 61, 461-466. [CrossRef]

47. Bae, S.Y.; Myslinski, J.M.; McMahon, L.R.; Height, J.J.; Bigley, A.N.; Raushel, F.M.; Harvey, S.P. An OPAA enzyme mutant with increased catalytic efficiency on the nerve agents sarin, soman, and GP. Enzym. Microb. Technol. 2018, 112, 65-71. [CrossRef]

(C) 2019 by the authors. Licensee MDPI, Basel, Switzerland. This article is an open access article distributed under the terms and conditions of the Creative Commons Attribution (CC BY) license (http://creativecommons.org/licenses/by/4.0/). 